\title{
Quality Of Life in The Elderly With Dizziness Complaint: Nova Friburgo City - Brazil
}

\author{
Pinheiro BAP ${ }^{1}$ and Felipe $\mathrm{L}^{2 *}$ \\ ${ }^{1}$ Speech Pathologist and Audiologist, Fluminense Federal University, Brazil \\ ${ }^{2}$ Coordinator and Professor at Fluminense Federal University, Rio de Janeiro, Brazil
}

Submission: March 04, 2016; Published: March 22, 2017

*Corresponding author: Lilian Felipe, Coordinator Speech Pathologist and Hearing Sciences, Professor at Fluminense Federal University, 22, Dr Silvio Henrique Braune, Center, Nova Friburgo, Rio de Janeiro, Brazil, Zip Code: 28625-650, Email: Lilianfelipe@id.uff.br

Abstract

Introduction: As life expectancy increased, complaints of dizziness became more common, leading to a decline in the quality of life of the elderly population.

Objective: To verify the presence of a complaint of dizziness and the impact caused by it in the quality of life of the elderly in the municipality of Nova Friburgo / RJ.

Methodology: Cross-sectional study. Elderly people aged 60 years or more were interviewed from the different districts of the municipality. An elaborated questionnaire was used, with closed questions about the type of dizziness, duration and time of the complaint, and the questionnaire on Brazilian DHI quality of life, composed of 25 objective questions that assess the physical, emotional and functional aspects.

Results: 239 elderly people participated in the study, with a mean age of 69.9 years, of which $72.8 \%$ were female. $75.4 \%$ of the elderly had dizziness at least once in the last year. There was no statistically significant difference in age between the groups with and without dizziness ( $p$ $=0.17)$, nor when the groups were female $(p=0.41)$ and male $(p=0.33)$. Comparing the variables related to the DHI questionnaire in subjects complaining of dizziness, there was no statistically significant difference comparing the complaints related to the physical $(p=0.89)$, emotional $(\mathrm{p}=0.78)$ and functional $(\mathrm{P}=0.38)$.

Conclusion: Dizziness is a frequent complaint among the interviewees, representing almost half of them. From the questionnaire it was verified how dizziness affects the quality of life in all aspects.

Keywords: Dizziness; Prevalence; Aging; Vertigo

\section{Introduction}

Nowadays, it is possible to observe not only in Brazil, but in other countries, a great change in relation to life expectancy and, consequently, an increase in the elderly population. According to data from the United Nations (UN), in 2000 there were 606 million elderly people in the world [1-6]. It is estimated that by 2050 the elderly population reaches two billion individuals, mostly in developing countries. In this way, a higher number of elderly people are predicted than those of children up to five years. The aging process occurs due to factors such as: decrease in fertility rate and mortality and increase in life expectancy Costa et al. [7].

There is a growing trend in the number of older people around the world today. According to the WHO (2002), individuals aged over 60 years are considered elderly in developing countries; in developed countries, this age rises to 65 years. In Brazil, according to the National Policy of the Elderly, Law No. 8,842 of January 4,1994, as well as the Statute of the Elderly, Law No. 10,741 of October 10, 2013, it is considered elderly any person over 60 years [8-12]. For this reason, there is transition and modification of the age pyramid, where the base that is composed of young people narrows and the top that is composed by the elderly, widens. According to the latest survey conducted in Brazil in 2010 by the Brazilian Institute of Geography and Statistics (IBGE), the Brazilian population is made up of more than 190 million people, out of which more than 20 million $(10.8 \%$ ). Are older people and are expected to reach a total of 31 million people, over 60 years of age by 2020 , integrating it into the world panorama of increasing human longevity (KÜCHEMANN, 2012). 
Thus, the aging process can be considered a reality for most people, due to better living conditions, advances in both technology and medicine, increased concern and feeding, all contributing to an increase in the expectation and quality of life of this population. On the other hand, as a consequence of the aging process, there is an increase in the number of cases of chronic diseases related to this new reality. Among the most prevalent complaints, dizziness is found as the second most observed complaint. It is known that the body balance disorder directly affects the quality of life of the elderly, which can reduce their autonomy, causing fear and insecurity, besides the risk of falls, being one of the most frequent causes of death in this group.

The improvement of the quality of life starts from the knowledge of the population and their needs. Studies involving only the elderly population are scarce in Brazil, and to date, there are no data related to dizziness in the city of Nova Friburgo, a mountain region of the state of Rio de Janeiro. Therefore, this study is justified by the necessity and importance of evaluating the presence of the complaint of dizziness and its impact on the quality of life in the elderly population of Nova Friburgo.

\section{Materials and Methods}

This is a cross-sectional study. The research was approved by the Ethics and Research Committee under number 479.131 / 2013 in compliance with Resolution 466/12, of the National Health Council (CNS), referring to research ethics involving human beings. All participants were informed about the theme and purpose of the research, and then those who agreed to participate signed the Informed Consent Form CNS 466/12, confirming that they agreed and that their data were used exclusively for scientific purposes. The inclusion criteria were: elderly people of both sexes, residents of the different districts of Nova Friburgo-RJ (Riograndina, Paulino Counselor, Mury, Center) aged 60 or over. Exclusion criteria were: Difficulty of locomotion, neurological diseases, motor disorders, cognitive, hearing or vision deficits.

It was initially asked if the elderly person reported a dizziness complaint in the last year (2015). Dizziness has been characterized by type (vertigo or dizziness), duration (less than one minute, between one minute and one hour, greater than one hour), how long has the complaint been filed (for more than 5 years, between 1 and 5 Years, less than 1 year), how often it occurs (daily, weekly, monthly, or annually). To verify the impact caused by dizziness in elderly QoL, the Brazilian DHI questionnaire (Annex 2) was used, consisting of 25 objective questions that evaluate the physical, functional and emotional subscales. The score varies from 0 points to 100 points and the higher the score, the greater the damage caused by dizziness in the QoL of this population.

For the statistical analysis, the independent $\mathrm{T}$ test was used for the calculation of means and the Wilcoxon test, nonparametric test for comparison of two paired samples, for comparison between the groups with and without dizziness. In all analyzes the significance level of $5 \%$ was considered. The groups were compared in relation to the variables of age, sex, with and without complaint of dizziness.

\section{Results}

According to the latest IBGE survey (2010), in the municipality of Nova Friburgo / RJ, the total population was 182,082 inhabitants, and could reach 185,102 in 2016. In 2010, the elderly represented about 26,089 inhabitants (14.2\%). For this research, approximately $1 \%$ of the total elderly population living in the municipality were interviewed. A total of 239 elderly people, aged between 60 and 90 years, with a mean age of 69.9 years and a standard deviation \pm 7.15 participated in the study. There were $174(72.8 \%)$ females and 65 (27.2\%) males [13-18].

Of the 239 elderly interviewed, 118 (49.3\%) reported dizziness in the last 5 years, of which 89 (75.4\%) also presented dizziness at least once in the last year. Regarding the type of dizziness, the elderly were instructed to describe how they felt during the seizures. For dizziness was considered as complaint the feeling of imbalance / instability and for vertigo was considered the feeling of feeling the head spin or everything that is around spin. Regarding the duration of symptoms, it was observed that in 77 elderly (65\%) their time is less than 1 minute. It was observed that in 44 elderly people (37\%), dizziness occurs at least once a month. In 66 elderly people (57\%), the time of complaint of dizziness varied between 1 and 5 years. The age distribution between the groups did not present a statistically significant difference, being the $\mathrm{P}$ value by the Wilcoxon test of 0.17 (Figures 1-4).

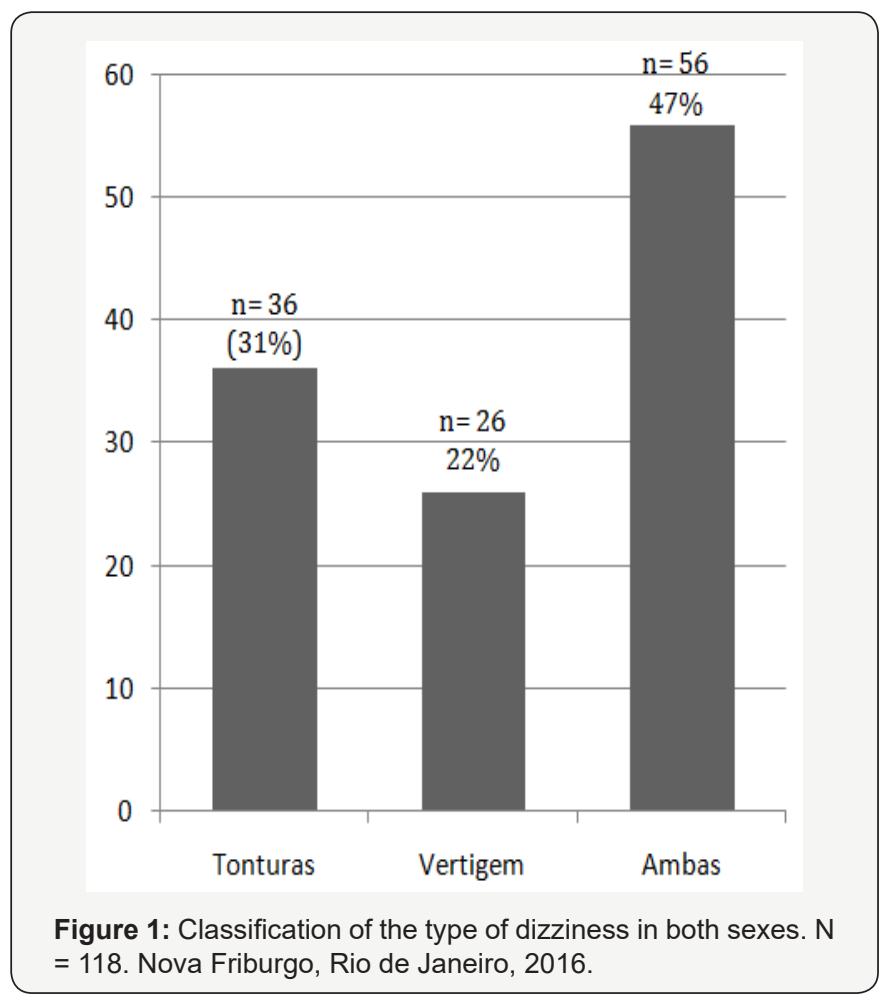




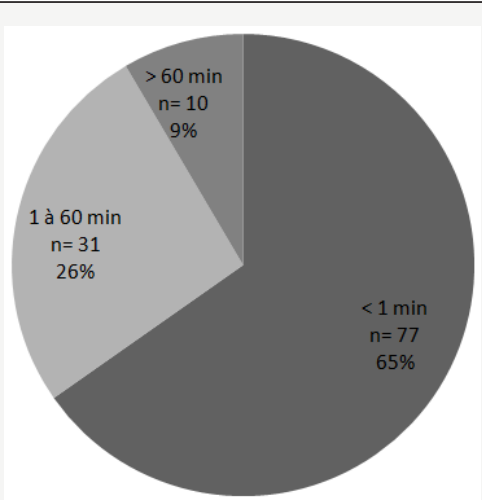

Figure 2: Duration of symptoms in both sexes. $N=118$. Nova Friburgo, Rio de Janeiro, 2016.

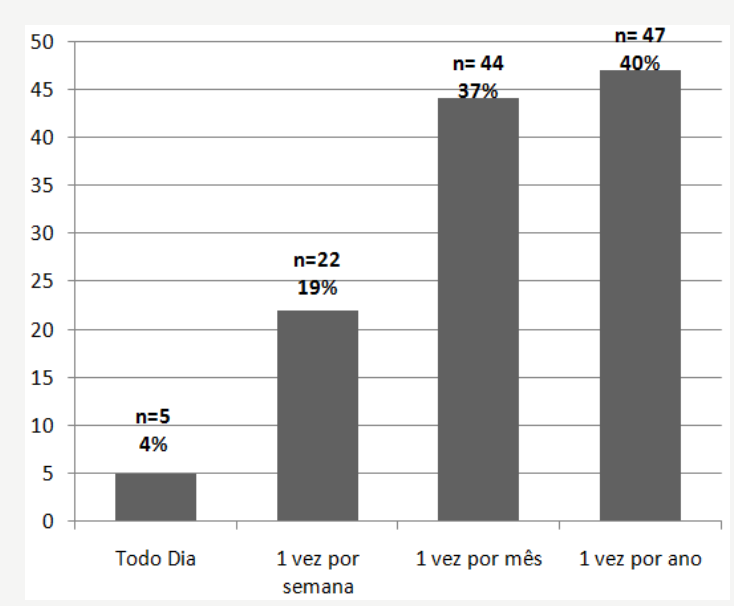

Figure 3: Occurrence of dizziness in both sexes. $\mathrm{N}=118$. Nova Friburgo, Rio de Janeiro, 2016.

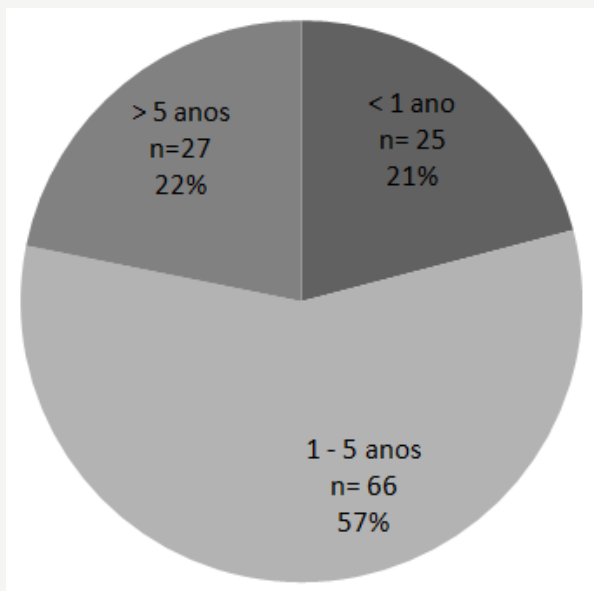

Figure 4: Time of onset of dizziness symptoms in both sexes. $\mathrm{N}$ = 118. Nova Friburgo, Rio de Janeiro, 2016.

The distribution by sex, comparing the group with dizziness and the group without dizziness, did not present a statistically significant difference, being the result of the $\mathrm{P}$ value by the Wilcoxon test for the female sex of 0.41 and for the male sex of 0.33 . The distribution by sex, comparing the variables physical, emotional and functional, did not present a statistically significant difference, being the value of $\mathrm{P}$ by Wilcoxon test of $0.89 ; 0.78 ; 0.38$, respectively. The TAB 4 represents the mean of the impact scores caused by dizziness in the QoL of the elderly of both sexes. When comparing the variables evaluated by the Brazilian DHI, a statistically significant difference was observed between the physical and emotional variables $(p=0.01)$, emotional and functional variables $(p=0.04)$ (Tables 1-5).

Table 1: Comparative distribution by age in relation to groups with and without dizziness of both sexes. $\mathrm{N}=239$. Nova Friburgo, Rio de Janeiro, 2016.

\begin{tabular}{|c|c|c|c|c|c|c|}
\hline Grupos & N & Média & Desvio padrão & Mediana & Mínimo & Máximo \\
\hline COM TONTURA & 118 & 70,6 & 7,11 & 71 & 69 & 72 \\
\hline SEM TONTURA & 121 & 69,2 & 7,13 & 69 & 68 & 71 \\
\hline
\end{tabular}

Table 2: Comparative distribution in relation to age in females. $N=174$. Nova Friburgo, Rio de Janeiro, 2016.

\begin{tabular}{|c|c|c|c|c|c|c|}
\hline Grupo com e sem tontura & N & Média & Desvio padrão & Mediana & Mínimo & Máximo \\
\hline FEMININO COM TONTURA & 99 & 70,5 & 7,4 & 70 & 69 & 72 \\
\hline FEMININO SEM TONTURA & 75 & 69,9 & 7,54 & 69 & 67 & 72 \\
\hline
\end{tabular}

Table 3: Comparative distribution in relation to age in males. $N=65$. Nova Friburgo, Rio de Janeiro, 2016.

\begin{tabular}{|c|c|c|c|c|c|c|}
\hline Grupo com e sem tontura & N & Média & Desvio padrão & Mediana & Mínimo & Máximo \\
\hline MASCULINO COM TONTURA & 19 & 70,2 & 5,66 & 71 & 67 & 73 \\
\hline MASCULINO SEM TONTURA & 46 & 68,7 & 6,28 & 67,5 & 67 & 73 \\
\hline
\end{tabular}


Table 4: Results of Brazilian DHI scores in elderly with dizziness. N = 118. Nova Friburgo, Rio de Janeiro, 2016.

\begin{tabular}{|c|c|c|c|c|c|c|}
\hline Dhi brasileiro & Variação da pontuação & Média & Desvio padrão & Mediana & Valor mínimo & Valor máximo \\
\hline ESCORE TOTAL & $0-100$ & 23,85 & 8,51 & 4 & 0 & 100 \\
\hline ASPECTO FÍSICO & $0-28$ & 8,64 & 7,51 & 8 & 0 & 28 \\
\hline ASPECTO EMOCIONAL & $0-36$ & 7,45 & 9,81 & 4 & 0 & 36 \\
\hline ASPECTO FUNCIONAL & $0-36$ & 8,08 & 8,09 & 6 & 0 & 36 \\
\hline
\end{tabular}

Table 5: Mean, standard deviation and median of the Brazilian IHD variables compared to each other. $\mathrm{N}=118$. Nova Friburgo, Rio de Janeiro, 2016.

\begin{tabular}{|c|c|c|c|}
\hline Variáveis & Média & Desvio Padrão & Mediana \\
\hline FÍSICO E EMOCIONAL & 8,05 & 8,74 & 4 \\
\hline FÍSICO E FUNCIONAL & 8,36 & 7,79 & 6,01 \\
\hline EMOCIONAL E FUNCIONAL & 7,76 & 8,98 & 4 \\
\hline
\end{tabular}

\section{Discussion}

As the elderly population increases, the number of complaints related to dizziness becomes more and more frequent, as it directly affects the QoL of this population. According to the literature, the average complaint ranges from $13 \%$ to $38 \%$ depending on the population studied. For the elderly population, this average is around 30\% Tinkett et al. [18] Collett et al. [6]. In the present study, the prevalence of dizziness was $49.3 \%$, a high number when compared to the world average, but it is in agreement with the national findings, in which the average was $45 \%$ and $44 \%$ Moraes et al. and Bittar et al. [2].

Dizziness can be characterized with dizziness or dizziness called vertigo or non-rotational. In this study, almost half of the elderly (47\%) reported an association between both types of dizziness. In the study by Gazzola et al. (2006), the prevalence by this association was also higher in the sample studied (68.3\%). However, in the literature we found a higher prevalence due to rotational dizziness Felipe et al. [9] Huang et al. [11] Scherer et al. 2012; BITTAR et al.[2]. In this research, short-term episodes were reported, going against the study by FELIPE et al. [9] and 66 elderly (57\%) complain of dizziness between 1 and 5 years, agreeing with MORAES et al. [16].

In the analysis of the sex variable, it was verified that dizziness was more observed in the female sex than in the male sex, going against the literature $[9,16]$ GANANÇA et al. GAZZOLA et al. 2006 in which the ratio is 2: 1 . However in this study the proportion was 5: 1 . This higher proportion of females may be related to the fact that women are more concerned with health and seek more medical help in relation to men, besides the influence of hormonal factors BITTAR et al.[1]. When comparing the groups by sex and age, there was no statistically significant difference, but no studies were found on this variable to compare the results.
The Brazilian DHI was the questionnaire chosen because it was considered reliable, easy to apply and used in several studies. (Baker et al. 2007). In relation to the aspects evaluated by the Brazilian DHI, a greater impact was observed in the physical aspect, followed by the functional aspect and finally the emotional aspect, corroborating with the findings of CASTRO et al. [5]; Moreira et al. (2006). In this questionnaire, the physical aspect aims to assess the worsening of dizziness during head, eye and body movements.

The findings of the aspects evaluated by the Brazilian DHI are in agreement with the findings of CASTRO et al. [5] in which there was a statistically significant difference between these aspects. We can observe that in the two analyzes, the emotional aspect is present, going against the studies in which dizziness leads the elderly to feel insecure, with fear, low self-esteem and autonomy, reducing their QoL (INÁCIO, 2011, And other factors that may contribute to the development of this type of activity Leite et al. [15].

\section{Conclusion}

In this study, the complaint of dizziness was observed in almost half of the elderly, being its frequent occurrence, of short duration, with prevalence in the female sex. There was no statistically significant difference when compared to age groups, since both had the same mean age. Regarding quality of life, it was observed that dizziness mainly affects the physical aspect, restricting the individual to perform activities and reducing their autonomy.

It is also highlighted, from the findings of Brazilian DHI, that dizziness is directly associated with feelings of insecurity and fear, causing a functional decline in the self-esteem of the elderly. From this study, the importance of the creation of programs of promotion, prevention, and treatment for the elderly population in the municipality of Nova Friburgo/RJ is verified. Moreover, it 
is fundamental to the health professional to know the functional characteristics of the balance, so that effective strategies are created for this population with complaints of dizziness, returning them to their autonomy as long as possible.

\section{References}

1. BITTAR RSM (1997) Labirintopatias hormonais: hormônios esteroides, estrógeno e progesterona. Int Arch Otorhinolaryngol 1(4):32.

2. Bittar RSM, Oiticica J, Bottino MA, Ganança FF, Dimitrov R (2013) Population epidemiological study on the prevalence of dizziness in the city of São Paulo. Braz J Otorhinolaryngol 79(6): 688-698.

3. BRASIL, LEI № 8.842, DE 4 DE JANEIRO DE (1994) Dispõe sobre a política nacional do idoso, cria o Conselho Nacional do Idoso e dá outras providências. Brasília, 4 de janeiro de.

4. BRASIL, Organização Pan-Americana da Saúde (2005) Envelhecimento ativo: uma política de saúde. Brasília-DF pp: 60.

5. CASTRO ASO, Juliana Maria Gazzola, Jamil Natour, Fernando Freitas Ganança (2007) Versão brasileira do Dizziness Handicap Inventory. Pró-Fono Revista de Atualização Científica 19.

6. Colledge NR, Wilson JA, Macintyre CC, MacLennan WJ. (1994) The prevalence and characteristics of dizziness in an elderly community. Age Ageing 23(2):117-120.

7. Costa EFA, Porto CC, Soares AT (2003) Envelhecimento populacional brasileiro e o aprendizado de geriatria e gerontologia. Revista da UFG $5(2)$.

8. Drachman D, Hart C (1972) An approach to the dizzy patient. Neurology 22(4): 323-334.
9. Felipe L, Luciana Cristina Matos Cunha, Fabiana Carla Matos Cunha, (2008) Presbivertigem como causa de tontura no idoso. Pró-Fono Revista de Atualização Científica 20(2): 99-104.

10. Ferreira Lmbb, Figueiredo Ribeiro KMO, Kenio Costa de Lima (2014) Prevalência de tontura na terceira idade. Rev CEFAC 16.

11. Huang WN, Xu J, Gao B, Zhou JM, Liu GF (2005) Study on the causes and risk factors on vertigo and balance disorders in 118 elderly patients. Zhonghua Liu Xing Bing Xue Za Zhi 26(9): 720-722.

12. Hueb MM, Feliciano CP (2012) Avaliação diagnóstica das síndromes vertiginosas. Revista do Hospital Universitário Pedro Ernesto 11.

13. IBGE (2015) Síntese de indicadores sociais : uma análise das condições de vida da população brasileira. Coordenação de População e Indicadores Sociais. - Rio de Janeiro:IBGE, 35.

14. IBGE (2013) Síntese de indicadores sociais uma análise das condições de vida da população brasileira. Rio de Janeiro;IBGE 32.

15. Leite HR (2011) Reabilitação vestibular em idosos. Revisão de literatura. Revista digital. Buenos Aires. Ano 16: 156.

16. Moraes SA, Fett WC, Ferriolli E, Perracini MR, Rodrigues RA, et al. (2011) Dizziness in community - dewelling older adults: A population based stud. Braz J Otorhinolaryngol (Impr) 77(6): 691-699.

17. Oms - Organização Mundial Da Saúde (2015) Relatório mundial de envelhecimento e saúde.

18. Tinetti ME, Williams CS, Gill TM (2000) Dizziness among older adults: a possible geriatric syndrome. Ann Intern Med 132(5): 337-344.

\section{Your next submission with Juniper Publishers will reach you the below assets}

- Quality Editorial service

- Swift Peer Review

- Reprints availability

- E-prints Service

- Manuscript Podcast for convenient understanding

- Global attainment for your research

- Manuscript accessibility in different formats

( Pdf, E-pub, Full Text, Audio)

- Unceasing customer service

Track the below URL for one-step submission https://juniperpublishers.com/online-submission.php 